\title{
Towards a product independent ERP training model: An Insight from a literature review
}

\author{
Seyed Mohammad Motahar \\ National University of Malaysia (UKM) \\ United Nations University International Institute for Global Health (UNU-IIGH) \\ inventiontime@gmail.com
}

\section{Muriati Mukhtar}

National University of Malaysia (UKM)

\section{Nurhizam Safie}

United Nations University International Institute for Global Health (UNU-IIGH)

\section{Muhamad Yusnorizam Ma'arif}

National University of Malaysia (UKM)

\section{Shima Mostafavi}

North Metropolitan TAFE,

Western Australia

\section{Abstract}

ERP can be called as one of the most significant contributions of computer science and particularly information systems for the business environment which can support all complicated business process of an organisation including sale, purchase, warehouse and manufacturing into a single database. For such complex system like ERP, implementation involves much collaboration which raises the concern of the success of the project. Among most significant success and failure factors of ERP implementation cited in the literature are training and consultation. For many years the majority of ERP vendors promote their product specific training models as long-term and expensive allowing the organisation to gain knowledge of the ERP system and the way it handles the business process. However, recent studies showed that ERP training can be conducted in the short term and with minimum investment and yet to be effective. Findings triggered a signal and opened a new door for research to investigate vendor-independent training models that require limited investment in training and consultancy. This paper aims to provide an overview of the literature; highlighting the research methods and theories used by authors towards building ERP training models and methods.

Keywords: ERP, ERP Training, ERP Teaching, ERP Learning

\section{Introduction}

Among most important success and failure factors of ERP Implementation cited by the literature are training and consultation (Noudoostbeni, Yasin, \& Jenatabadi, 2009a) which allows the organisation to gain knowledge of the ERP system and how it handles the business process. This information is especially needed since during implementation, there need to be a mapping and alignment of business process with features of ERP systems which need proper understanding of ERP systems. Therefore training is among the most critical success factor identified by researchers and is a major phase in implementation procedure of ERP systems (Kale \& Kale, 2000) (Sumner, 1999). Despite the critical role of ERP training, there are limited 
studies attempted to go further by conducting experiments to investigate ERP training models and methods that are independent of the vendor and their product.

Results of our preliminary study showed that majority of the research articles in the area of ERP systems training are product specific and top vendors like $S A P \AA$, Oracle ${ }^{\circledR}$ and Microsoft ${ }^{\circledR}$ are promoting their ERP certification programs following their ERP training models and methods in the market. It is evident that an adequate ERP training should not only focus on theoretical aspects. It should be supported by hands-on exercise to make sure participants have gained practical skills to use a product. However, such training programs may not be seen as a viable option for many companies due to two simple reasons, cost and time.

Majority of ERP vendors suggest a long-term continuous training programs for their ERP packages (S. Koh, A. Gunasekaran, \& J. Cooper, 2009). An example is SAP that suggests "continuous process of lifelong learning" (Noudoostbeni, Ismail, Jenatabadi, \& Yasin, 2010) and past research in the area of ERP systems and ERP training seem to accept that as a fact. Majority of the research was done following such long-term training models and methods recommended by vendors.

In addition to the time, the cost is another factor since such training classes provided by vendors are expensive (Bradford, Vijayaraman, \& Chandra, 2003). ERP just like any other enterprise systems are costly, and it is estimated that $50-75 \%$ of enterprise systems implementation failed to justify the huge investment in the project. Literature reported that training related factors are the main contributors to the failure of the project. (C. Arasanmi, Wang, Singh, \& Ekundayo, 2011). Therefore training is reported to be one of the expensive elements of the ERP implementations and vendors recommended allocating extra budget to cover the expensive cost of training (José Manuel Esteves, Carvalho, \& Santos, 2001).

There is no doubt that ERP training models and methods provided by top vendors follow their business strategy. This strategy pushes learners toward certification programs that are expensive and is becoming one of their main revenue streams. For example, a wide range of courses and e-learning materials are available and provided by SAP, and it is unsurprising that about $11 \%$ of the company income is the revenue coming from the training programs (Aldrich, 2000; Montandon \& Zentriegen, 2003).

Such expensive and "continues the process of lifelong learning" is subject to criticisms and concern from experienced professionals where training models supported by certifications may not be appropriate and necessary for all candidates. Hitchcock cited critics from a top rank forum contributor who criticised such certifications to be expensive for three reasons:

"To ensure that one invests so much they will never recommend any other product; to enable certification vendors to claim large numbers of certified professionals supporting their products; and the money it brings" (Hitchcock, 2005).

Despite the fact that many research articles in the ERP area are addressing a comprehensive and ongoing training cycle for ERP adoption, findings from a study conducted by (S. Koh et al., 2009) on a training model devised by an ERP vendor reveal that ERP systems can be implemented by end users by attending a very short course instead of the external consultancies.

The training model of the case company was not discussed in Koh's article (2009) and the main objective of Koh's work was to check the validity of the claim. 
Therefore, our study aims to continue this work by reviewing the literature in the area of ERP training and to represent the current status of knowledge as well as to investigate the research methods and theories used by authors towards a 'product independent' ERP training model.

The following sections of this paper is organized as follows: Research methodology section introduces the approaches used to collect data from the sources, the findings section, provides a detailed analysis of the articles included in the process of the systematic literature review and provides the result in a data table. The discussion provides a detailed description of the articles collected and their contributions toward the topic. Last but not least, the conclusion section summarises the gaps in the literature that needs more attention from researchers.

\section{Research Methodology}

In our research, we follow systematic review approach, an effective method of conducting a literature review (Bryman, 2012). This method involves a review of the literature using online databases in step by step procedure.

We started by using "ERP Teaching" and "ERP Training" as the initial keywords and applied a search filter to show results containing the keywords in the title of the paper. The industry makes most of the contributions in the area of ERP training. Therefore, the initial search was done on Google Scholar ${ }^{\circledR}$ with the aim of capturing academic papers contributed by industry. Also, keywords and filters were applied in two major academic databases, Scopus and Web of Science (WoS) to capture top-tier papers in journals and conferences. The authors carefully reviewed all the results by scanning the abstracts and excluded irrelevant results from above three sources. In addition to that, to have better coverage in the area of study, references for selected papers have been analysed to identify possible relevant sources to add to the repository. As a result, authors convinced that majority of the papers in Scopus and Google generated scholar are industry relevant and in most cases they just examined the training models and methods that top ERP vendors provided in their training channels. Since the objective of our work is to focus on vendor-independent training models and methods, we decided to exclude Google Scholar and Scopus from our literature review. This is done in order to ensure that an academic foundation and high quality works can be captured within a proper academic method. Therefore, the optimised keywords used to search the ISI web of knowledge ${ }^{\circledR}$, and at the end, the repository was analysed, and findings of the results are discussed in the next section. Figure 1 demonstrates the process of extracting journals from the source. 

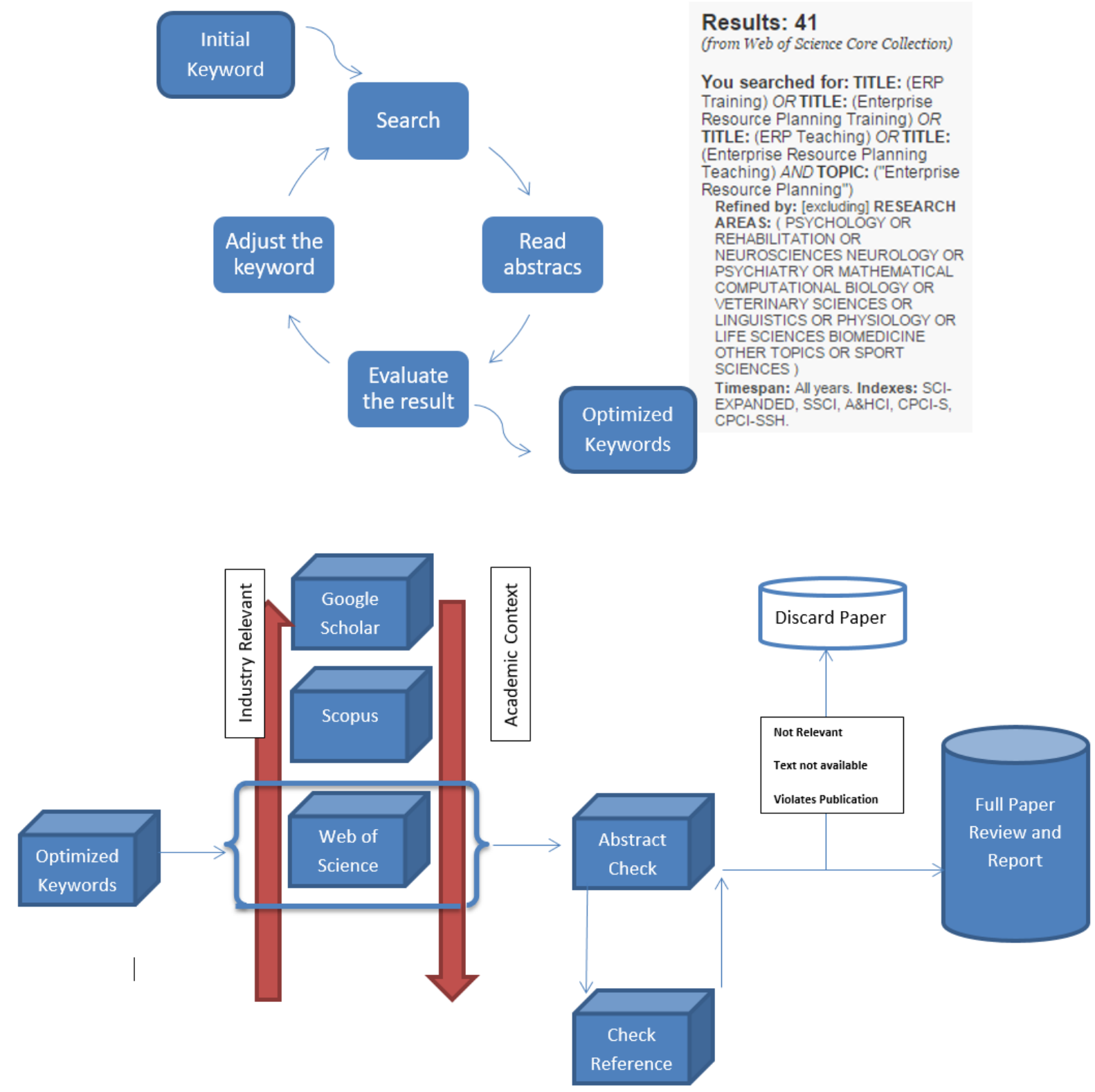

Figure 1 The Process of extracting journals from the sources

\section{Findings}

The papers were analysed, and their full text had been extracted from ISI Web of Knowledge®. There were few papers excluded from the discussion like (Shea \& Khalil, 2004) which we could not find the abstract from the publisher's website. There was also a paper that has been found to be in violation of IEEE's Publication Principles (Jing, Hua, \& Ieee, 2008) and therefore its text was not analysed in our review process. Table 1 provides a detailed analysis of the articles included in the process of the systematic literature review. In general, as shown in Figure 2 six different themes emerged from the review that includes ERP training models, Importance of ERP training, Usability of ERP training, ERP training and user satisfaction, ERP training evaluations. 


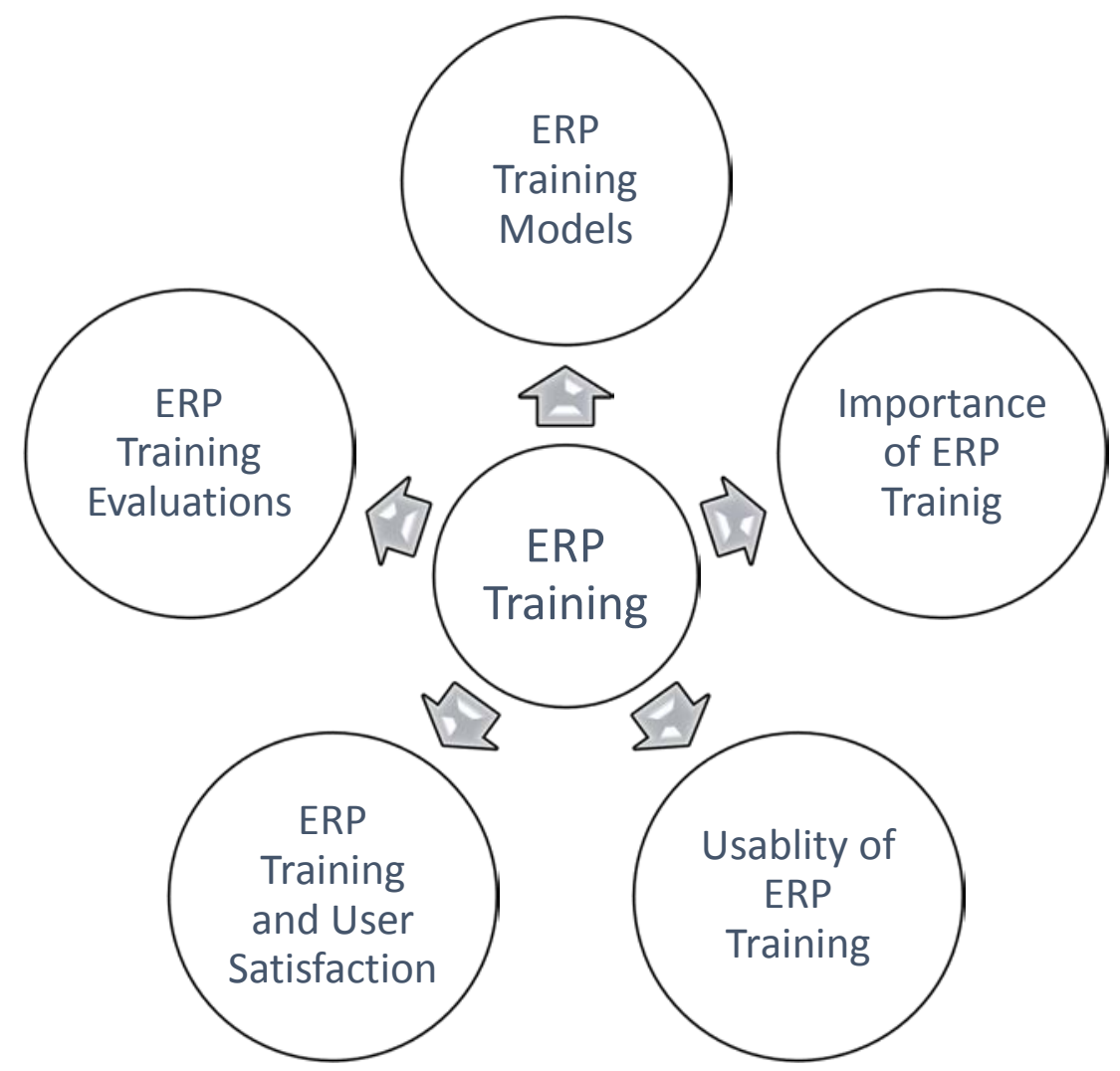

Figure 2 ERP Training research themes 


\begin{tabular}{|c|c|c|c|c|c|c|c|c|c|c|}
\hline \multicolumn{2}{|c|}{ Product Type } & \multicolumn{2}{|c|}{ Audience } & \multicolumn{5}{|c|}{ Research Theme } & \multirow[b]{2}{*}{ Topic } & \multirow[b]{2}{*}{ Author } \\
\hline $\begin{array}{l}\text { Open } \\
\text { Source }\end{array}$ & Proprietary & User & $\begin{array}{l}\text { Super } \\
\text { user }\end{array}$ & \begin{tabular}{|c|}
$\begin{array}{c}\text { Importance } \\
\text { Training } \\
\text { CSF }\end{array}$ \\
\end{tabular} & Usability & User Satisfaction & $\begin{array}{l}\text { Evaluations } \\
\text { Effectiveness }\end{array}$ & \begin{tabular}{|l} 
Models \\
Methods
\end{tabular} & & \\
\hline & $\mathrm{Y}$ & $\mathrm{Y}$ & & & $\mathrm{Y}$ & Y & & & Factors influencing Computer Self efficiency to use multimedia ERP & (Scott \& Walczak, 2009) \\
\hline & $\mathrm{Y}$ & $\mathrm{Y}$ & & & & & $\mathrm{Y}$ & & Propose new training approach & (Albadri \& Abdallah, 2009) \\
\hline & $?$ & $\mathrm{Y}$ & & & & & & $\mathrm{Y}$ & e-learning success model based on flow theory & (LinkedIn, 2015) \\
\hline & $\mathrm{Y}$ & $\mathrm{Y}$ & & & $\mathrm{Y}$ & & $\mathrm{Y}$ & & Effectiveness of the training manuals & (Ali, 2014) \\
\hline & & $\mathrm{Y}$ & & $\mathrm{Y}$ & & & & $\mathrm{Y}$ & Assembled a derived set of training best practices & (J. M. Esteves, 2014) \\
\hline & $\mathrm{Y}$ & $\mathrm{Y}$ & & & & & & $\mathrm{Y}$ & e-Learning adopting in ERP & (Dalveren, 2014) \\
\hline & & $\mathrm{Y}$ & & $\mathrm{Y}$ & & & $\mathrm{Y}$ & & Vocational Training on corporate operation performace & (Lin, Lin, \& Kao, 2013) \\
\hline & & $\mathrm{Y}$ & & & & & $\mathrm{Y}$ & $\mathrm{Y}$ & Evaluating an ERP teaching course based on CDIO principals & (Huang, Yu, \& Liu, 2013) \\
\hline & & $\mathrm{Y}$ & & & $\mathrm{Y}$ & & & $\mathrm{Y}$ & Effect of training content in ERP learning utilization & (C. N. Arasanmi, Wang, \& Singh, 2013) \\
\hline & & $\mathrm{Y}$ & & & & & $\mathrm{Y}$ & & Effectiveness of the ERP training program & (Pantelic, Pajic, \& Vujaklija, 2012) \\
\hline & & & $\mathrm{Y}$ & & & & & $\mathrm{Y}$ & Proposed and evaluatd a simulation system for ERP training & (Wang, Li, \& Yang, 2012) \\
\hline & & & $\mathrm{Y}$ & & & & & & Proposed the teaching practice to develop the entrepreneurial ability & (Zhang, Li, \& Chen, 2011) \\
\hline & $\mathrm{Y}$ & & $\mathrm{Y}$ & $\mathrm{Y}$ & $\mathrm{Y}$ & & $\mathrm{Y}$ & $\mathrm{Y}$ & Theorical Model of training to allow limited training and consultancy & (S. C. L. Koh, A. Gunasekaran, \& J. R. \\
\hline & $\mathrm{Y}$ & $\mathrm{Y}$ & & & & & & & Factors influencing Computer Self efficiency to use multimedia ERP & (Scott \& Walczak, 2009) \\
\hline & $\mathrm{Y}$ & $\mathrm{Y}$ & & & & & & $\mathrm{Y}$ & Review Training Methods and suggest a mixed method & (Noudoostbeni, Yasin, \& Jenatabadi, \\
\hline & $\mathrm{Y}$ & $\mathrm{Y}$ & & & & & & $\mathrm{Y}$ & Proposed a new training methodology (process-oriented training) & (Mozaffar \& Mozaffar, 2009) \\
\hline & $\mathrm{Y}$ & $\mathrm{Y}$ & & & & & $\mathrm{Y}$ & $\mathrm{Y}$ & Proposed a new training method around end-user characterization & (Albadri \& Abdallah, 2009) \\
\hline & $\mathrm{Y}$ & $\mathrm{Y}$ & & & & & & $\mathrm{Y}$ & proposed a new model for the development of ERP training material & (Macris, 2009) \\
\hline & & $\mathrm{Y}$ & & $\mathrm{Y}$ & & & & $\mathrm{Y}$ & Proposed a model of ERP training based on System Dynamic & (Ip, Lai, \& Lau, 2004) \\
\hline & & $\mathrm{Y}$ & & $\mathrm{Y}$ & & $\mathrm{Y}$ & & & Impact of training on intention to use ERP & (Fan, Guh, Chou, Ku, \& Sher, 2004) \\
\hline & $\mathrm{Y}$ & $\mathrm{Y}$ & & $\mathrm{Y}$ & & & & $\mathrm{Y}$ & Intranet-based Training Facilities ERP System Implementation & (Mahapatra \& Lai, 1998) \\
\hline
\end{tabular}

Table 1 Data table of the articles reviewed by categories 


\section{Discussions}

In this section, a detailed description of the articles collected is provided. The objective is to provide a summary of the findings of the papers in regards to ERP training and their contribution towards the topic.

In a recent study conducted in Taiwan, Shih studied the effects of Innovation Management (IM) and Vocational Training on the corporate operating performance of SMEs in Taiwan after implementing ERP systems. The findings showed the fulfilment of operation performance during ERP implementation stages, and employees addressed the importance of implementation. (Lin et al., 2013).

Wang made another attempt in China (Wang et al., 2012), with the objective of strengthening the training course for "ERP talents" and by viewing the system from a staff perspective. An ERP simulation system has been designed in the study. The simulation system that has been designed by the author has two parts, operational part for students and administration part for managers. The objective is to separate the business modules from management related modules. So the students can run simulated operations using sub-modules within the operational part and managers can use the sub-modules of the administration part to run management operations. The system has been designed using advanced Java technologies, including Structs2 and Spring and Hibernate for data access layer which allows the system to be scalable.

Despite the fact that many research papers in the ERP area are addressing a comprehensive and ongoing training cycle for ERP adoption, findings from a study conducted by Koh on a training model devised by an ERP vendor revealed that end users can implement ERP systems for SMEs by attending a very short course. This short training course provided by an ERP vendor in this study was only five days and consists of three days technical and two days administration courses. SME-specific ERP vendor studied as a case in this research claimed that their ERP system could be implemented and run in production by users with a very limited investment in the training course.

As Koh mentioned in his work, this area of research is novel, and the result of such research will be very useful for many SMEs seeking to minimise investment on training and consultancy (S. C. L. Koh et al., 2009). Koh's paper (S. C. L. Koh et al., 2009) would have been much more useful if he included the main elements of the model itself. The training model of the case company is not discussed (it may be due to the confidentiality requested by the vendor), and the main objective of Koh's work was to check the validity of the claim. Another objective of Koh's work was to identify key factors that influence the success of the model. He conducted in-depth interview and analysis feedbacks and experience of the clients of the case company to form a theoretical framework. Koh's finding suggests that simplified system design is one of the key factors that brings ease of use and allows adoption of the system with minimum effort of business process engineering (BPR).

Users who have prior experience of working with ERP systems is another key factor that could help end users to understand the process better and work with the system. However, highly experienced users who are responsible for implementing the software in the customer environment are the major key element that influenced the success of the model. 
It seems that the support environment was another contributor to the success of the training model. By studying in the case company, Koh identified three major tools that were used by the vendor to support clients including a test database and a training compact disc (CD) supplied, an extensive release notes document as well as support via telephone.

Koh's work triggered a signal and subsequently opened a new door for research to investigate training models that are short-term yet effective. The research also aims to allow power users to do the implementation themselves with minimum investment in training and consultancy.

In Malaysia, a research study was done to investigate the different training methods of ERP in SME sectors in Malaysia (Noudoostbeni et al., 2009b). Table 2 shows the summary of training methods identified by him. By studying Malaysian SMEs, he concluded that training is referred to as the most important critical success factor in ERP Implementation. The study then investigates further by evaluating the effectiveness of different training methods from the end user's perspective. His findings show that lecturer and on the job training and computer based training are among the most used training methods in Malaysian SMEs.

\begin{tabular}{|c|c|c|c|c|c|}
\hline $\begin{array}{l}\text { Computer- } \\
\text { Based } \\
\text { Training }\end{array}$ & CD-ROM & Lecture & $\begin{array}{l}\text { Self-Directed } \\
\text { Learning }\end{array}$ & $\begin{array}{l}\text { On the-Job- } \\
\text { Training }\end{array}$ & Simulation \\
\hline $\begin{array}{c}\text { Computer } \\
\text { provides the } \\
\text { learning stimulus }\end{array}$ & $\begin{array}{l}\text { Interaction with } \\
\text { training } \\
\text { material through } \\
\text { using joystick } \\
\end{array}$ & $\begin{array}{c}\text { Communication } \\
\text { through } \\
\text { speaking } \\
\end{array}$ & $\begin{array}{c}\text { Employees are } \\
\text { responsible }\end{array}$ & $\begin{array}{l}\text { Learning through } \\
\text { observing } \\
\text { peers }\end{array}$ & $\begin{array}{l}\text { Represent a real } \\
\text { life situation }\end{array}$ \\
\hline $\begin{array}{l}\text { Computer } \\
\text { analyzes the } \\
\text { responses }\end{array}$ & \multirow{5}{*}{$\begin{array}{c}\text { Interaction with } \\
\text { training } \\
\text { material through } \\
\text { using touch-screen } \\
\text { monitor }\end{array}$} & Cheap & $\begin{array}{l}\text { Learning without } \\
\text { an instructor }\end{array}$ & $\begin{array}{l}\text { Learning through } \\
\text { observing managers } \\
\text { performing }\end{array}$ & $\begin{array}{c}\text { Developing } \\
\text { managerial } \\
\text { skills }\end{array}$ \\
\hline \multirow{4}{*}{$\begin{array}{l}\text { Computer provide } \\
\text { feedback to the } \\
\text { trainee }\end{array}$} & & Less time & $\begin{array}{l}\text { Learning process } \\
\text { controlled } \\
\text { by the trainee }\end{array}$ & $\begin{array}{l}\text { Useful for training } \\
\text { new } \\
\text { hired employee }\end{array}$ & $\begin{array}{l}\text { Fidelity to the } \\
\text { equipment } \\
\text { that trainee will } \\
\text { encounter } \\
\text { on the job }\end{array}$ \\
\hline & & $\begin{array}{l}\text { For large group of } \\
\text { trainees }\end{array}$ & $\begin{array}{l}\text { Encourage new } \\
\text { employees to learn } \\
\text { actively }\end{array}$ & \multirow{3}{*}{$\begin{array}{l}\text { Less investment in } \\
\text { time and money for } \\
\text { material }\end{array}$} & $\begin{array}{l}\text { Fidelity to the } \\
\text { situation } \\
\text { that trainee will } \\
\text { encounter } \\
\text { on the job }\end{array}$ \\
\hline & & \multirow{2}{*}{$\begin{array}{l}\text { Supporting other } \\
\text { training } \\
\text { methods }\end{array}$} & $\begin{array}{l}\text { Gaining better } \\
\text { understanding of } \\
\text { working place }\end{array}$ & & \multirow{2}{*}{ Expensive } \\
\hline & & & $\begin{array}{l}\text { Reducing the costs } \\
\text { associated with } \\
\text { traveling }\end{array}$ & & \\
\hline
\end{tabular}

Figure 3 training methods of ERP in SME sectors in Malaysia (Noudoostbeni et al., 2009b)

In another study done by Mozaffar, she refers to the findings from Gartner and other sources that indicate the importance of the training in ERP implementation (Mozaffar \& Mozaffar, 2009). Then by introducing the impact of business process and its role in new techniques like 6sigma, Lean manufacturing, JIT, she argues that new enterprise systems (i.e. ERP, CRM, SCM, etc.) are evolving to respond to this change yet user training needs to be changed from a taskoriented approach to a process-oriented approach to allow end user to make use of the system in a more effective way that can contribute

In 2010, Albadri published a research paper in which they described the adoption of a new training model called the end-users characterization and competency building approach (EUCCB) (Albadri \& Abdallah, 2009). It was designed based on the existing theories of 
"training management cycle" and "iceberg competency model". The objective of the model was to improve the healthy level of ERP implementation, and the model was designed to be pluggable to the ERP implementation life cycle. The focus of the training model was to solve the ERP end-users' system acceptance in the post implementation phase of the ERP project to ensure the usage effectiveness of the ERP during the life cycle of the system. This is reported by the author to be around 10-50 years. Albadri \& Abdallah described the model as a series of relevant guidelines and procedures organised around four main components. Figure.4 shows the main elements of the EUCCB model.
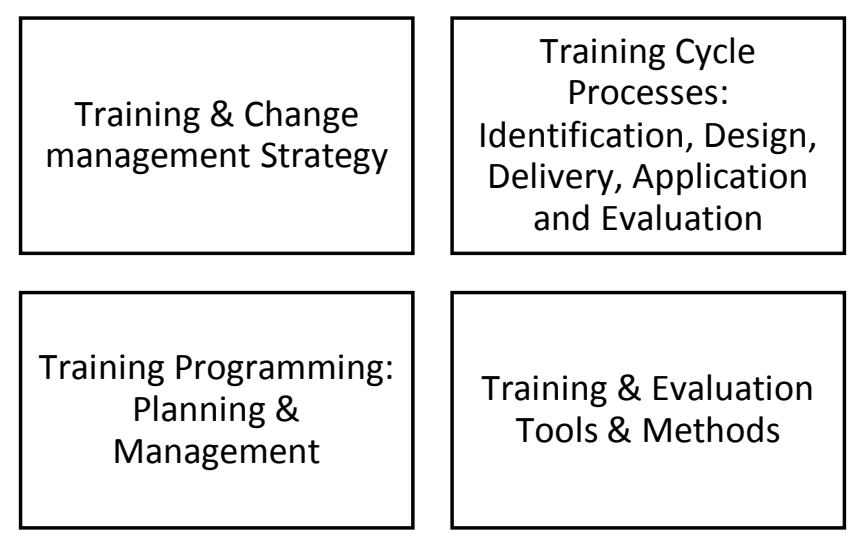

Figure.4 Main Elements of the EUCCB Model

Using the case study's research method, the described approach was adopted during the ERP implementation project in one of the major companies in the field of oil and gas in the United Arab Emirates.

The result of the survey reveals that there is an increased end-user acceptance rate. It was reported that $60 \%$ of end users participated in the survey were satisfied and found the training useful. Furthermore, during the knowledge test conducted by researchers, a group of end users who attended the training programs conducted as part of the (EUCCB) achieved a higher result.

Aristomenis has reported the first study of adopting the semantic web concept into the development of ERP training material in 2009 (Macris, 2009). In the paper, the author proposed a model to develop training materials for the ERP systems. By means of the case study method the usefulness of the new prototype model, a training scenario was chosen to develop an ERP training material for end users has been illustrated. The training scenario is focused on the meaning of the general ledger (GL) in the Microsoft Dynamics ERP package. Figure 5 demonstrates general ledger transactions scenario training aid based on semantic web principles.

In the case study of the scenario, two main components are created:

1. Transaction Scenario for GL account

2. User Interface of the scenario GL Account 
The author argues that the method which is based on the semantic web is focusing on capturing the existing knowledge. This method is used to represent it as ontology-based knowledge network which can provide additional benefits such as:

1. Semantic Search

2. Knowledge Navigation, and

3. Knowledge dissemination

The author claims that the model is designed to be used within existing methodologies to enhance the user satisfaction. Aristomenis claims that the method is not only applicable in the ERP area, but also in a wider range of training.

"This method is also highly transferable to the development of training materials for any kind of systems and users and can produce similar gains in learning and understanding in any domain of knowledge (Macris, 2009)"
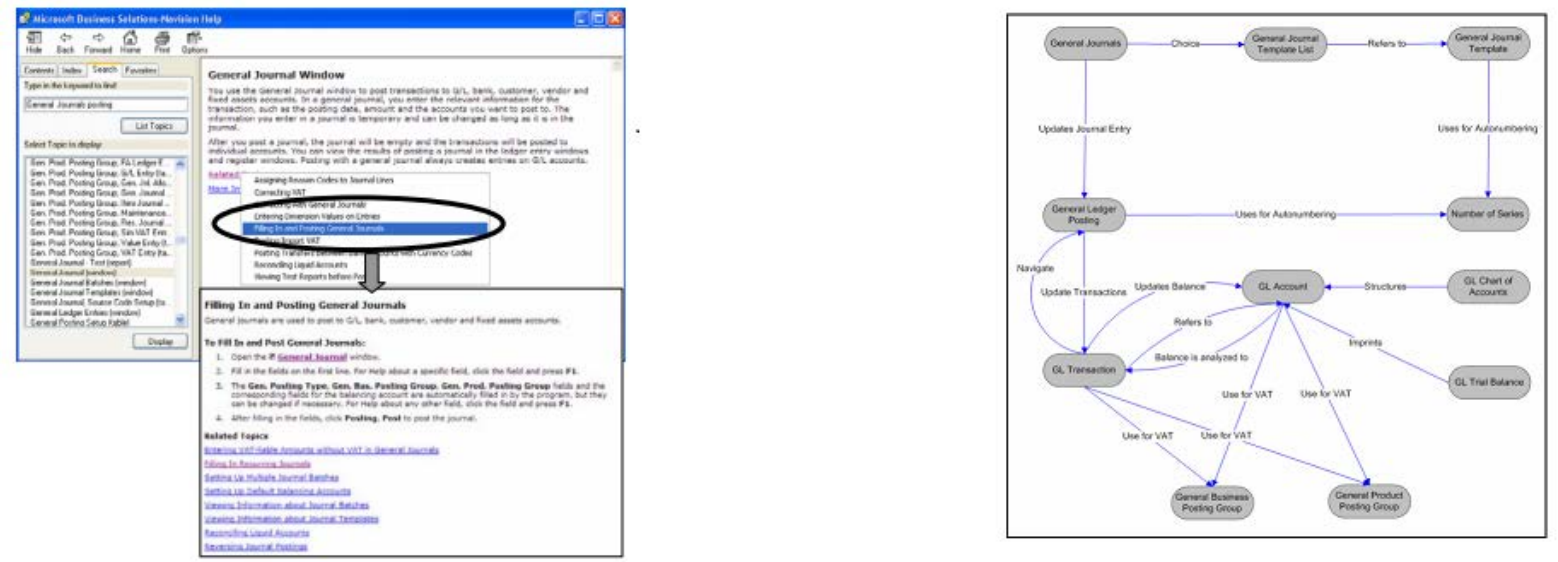

Figure 5 General Ledger (GL) Transactions Scenario Training Aid Based on Semantic Web Principles

Due to the novelty of the method, it may require further research to validate with more ERP process scenarios including more advanced workflows and different ERP implementation packages.

Another study was done to investigate the application of general system theory (GST) by Mahadevan (Mahadevan, Agbinya, Braun, \& Ieee, 2006). In this extensive research, a new strategic framework has been suggested, and the authors highlighted the role of GST in ERP training.

A logistics process which is among the challenging operational areas in any ERP implementation has been used, and the three different usability aspects of the ERP systems have been demonstrated in developing a business logistics management process. The authors conclude that "by using AHP method there will be an opportunity for a TC business system with formal usability trade-offs". Figure 6 shows three different aspects of ERP usability used by Mahadevan 


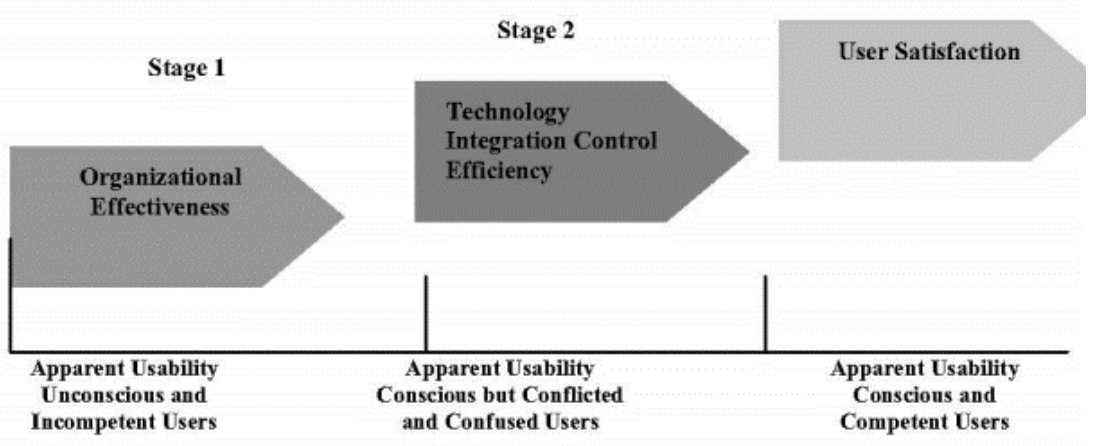

Figure 6 Three different aspects of ERP usability used by Mahadevan (Mahadevan et al., 2006)

Another study was done by Lee to investigate the impact of training satisfaction on the perceptions of ease of use in ERP Implementation (Lee \& Bradley, 2004). Qualitative data collection was done in the implementation of ERP in a higher education context. Results from the research identified the fact that there is a relationship between the job type and gender of trainees with the satisfaction of the training.

With the objective to overcome the lack of ERP training in ERP implementations, Dr Ip has applied the System Dynamic Theory in the training process of ERP systems (Ip et al., 2004). In the case study conducted by IP, An ERP training model has been proposed to simplify the training process in the manufacturing context. Figure 7 shows this ERP training model (Lee \& Bradley, 2004)

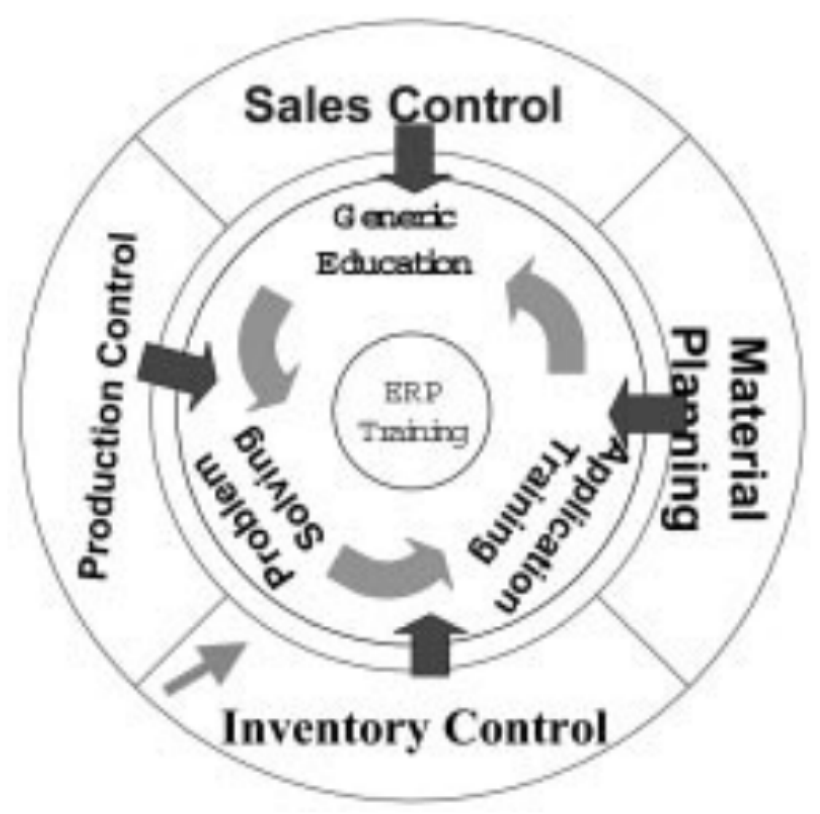

Figure 7 IP Training Model (Lee \& Bradley, 2004)

The model consists of three main elements that were incorporated into a website. Generic education provides a basic understanding of ERP and application training focusing on ERP system itself and how the system can allow performing functions. Within the constructive 
problem-solving part of the training is a series of problems that are in fact a day to day problems in the operations.

The model has been integrated with the web-based training system, and the result has been used as a framework for training in the case study company, namely a lamp manufacturer. The main objective of the system dynamic is to help scientists to understand objects in a system interacting with each other and not as an isolated object. The theory has been applied to solve many problems in different context ranging from a steam engine to a bank account or even a basketball team (Forrester, 1995) (Nelson \& Somers, 2001). Results from the study revealed benefits and usefulness of the model in the ERP context that can contribute to the success of ERP implementation.

The effect of computer self-efficacy and training on intention to use ERP has been investigated by Fan (Fan et al., 2004). The study is based on the technology acceptance model, and it examined the driving factors for end users to work with the ERP system. Using a survey instrument, a total of 202 responses were received from end users working with ten different companies. The result then analysed and author concluded that conducting an effective ERP training has a positive impact on perceived ease of use of ERP system for end user. In addition to that effective ERP training has an indirect positive impact on perceived usefulness, attitude, and intention to use ERP system for the end user (Fan et al., 2004).

Shtub in 2001 proposed a model of teaching and training of ERP systems (Shtub, 2001). Having a good understanding of the ERP systems for the managers and increasing inefficiency of training courses were the main objectives to design a new ERP training and teaching model. Shtub argue that ERP products are focusing on automating a business process and a complete process of sales can just go beyond sales module or a warehouse stock taking process can ultimately post into journals for automatic stock valuation and therefore the actual process within organization is supported by more than one module whereas ERP training course tend to focus on modules without considering the complete process.

Shtub's new ERP development framework consist of a build in interactive tool and a methodology to cover three main areas:

1. The traditional management of operations in a functional organisation.

2. The integrated and dynamic approach to operations

3. The use of advanced information systems (of the ERP type) to support the management of operations (Shtub, 2001)

Figure 8 demonstrates the Operation Trainer (OT )Method as a teaching aid that integrates the case study and the modelling. 


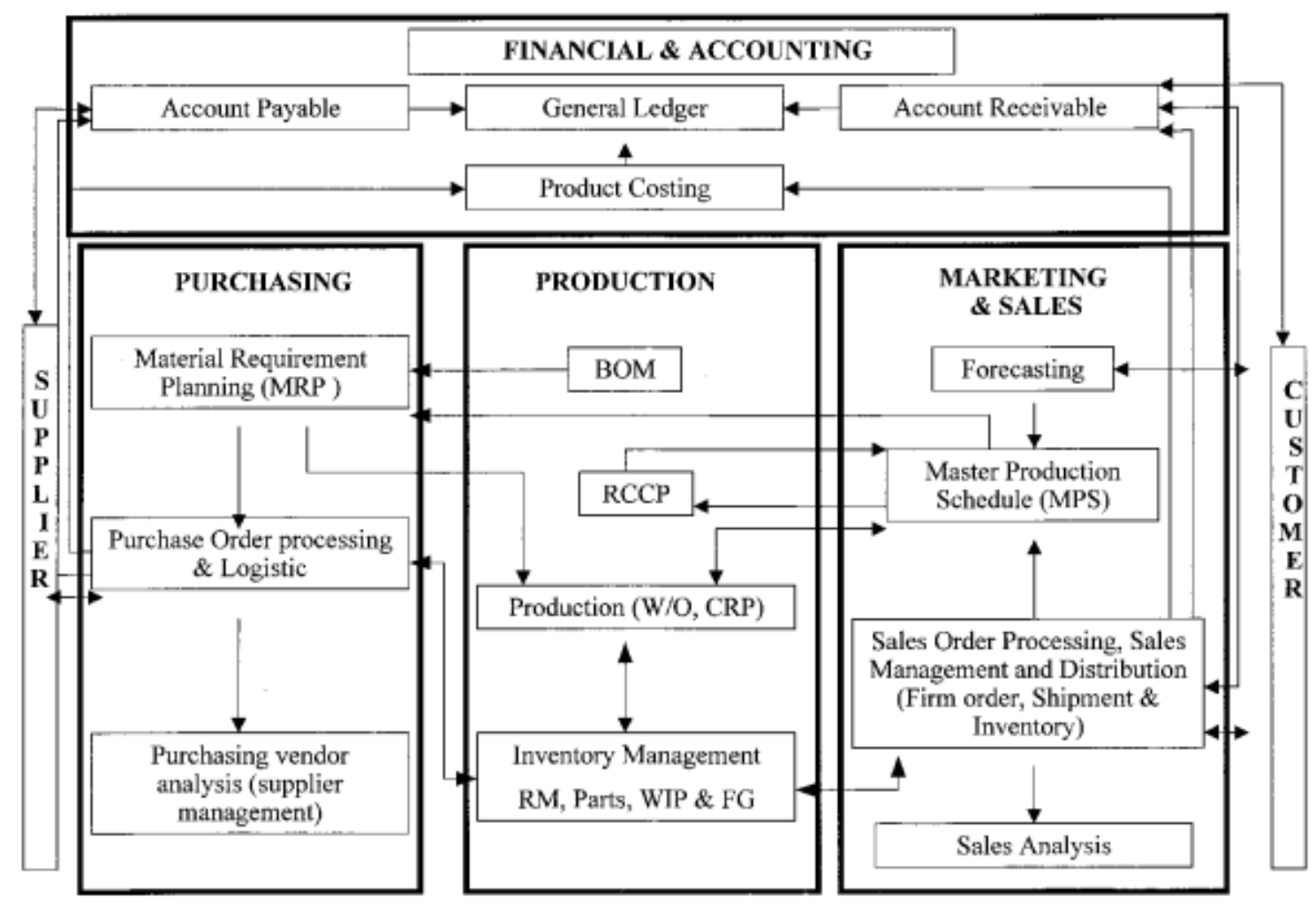

Figure 8 OT is a teaching aid that integrates the case study and the modelling (Shtub, 2001)

The new OT model was not only used in the industry training but also in university settings. The framework was applied to teach ERP implementation to managers. Results from the case studies demonstrate the effectiveness of the new ERP training model and its potential to be applied to teach complex process within ERP systems (Shtub, 2001).

In a project funded by United Nations University (UNU) Motahar proposed a new applied approach to teach ERP implementation using open source ERP framework. (Motahar, Safie, Mukhtar, Aljunid, \& Mostafavi, 2013). Motahar compiled a live ERP system and compiled as part of the course materials in pen drives and distributed to audience. Participants were asked to configure their own ERP package in every stage of the training by referring to the live and pre-configured version as a working example. At the end of the training course, The results from the training shows that end users can understand the complex business process and apply their knowledge by configuring a test instance and compare it along the way with a live and working version to validate their configuration.

\section{Conclusion}

As a summary, Findings from the literature shows that there are various methods and models examined by researchers for ERP training that are successful and promising. The results of applying those methods reveal that training can still be successful without following vendors training models that recommend "Continues life long learning" which is very expensive and not affordable especially for small and midsized enterprise (SME) and findings triggered a signal and opened a new door for research to investigate vendor-independent training models that require limited investment in training and consultancy. 
This article aimed to provide an insight from the literature review to highlight the research methods and theories that can be used towards building ERP training models and methods that are product independent. Based on our findings and discussion of the literature review of ERP training, we identified the following gaps in the literature that need more attention from researchers.

Although many papers presented training models and explored training methods, training methods and approaches suffer from a limitation regarding the targeted audience. There is a group of participants for ERP training. They are consultants and implementers. They are neither students who are lacking the knowledge of business process, nor end users who are working on a day to day basis with ERP package. There are limited training model or method found in the literature to investigate and address their needs.

In addition, although many papers presented training models for end users, most papers assumed that implementation is done alongside the training from the vendor. There is limited research to address a training approach that can allow end user not only to use the system but to be able to implement and maintain it. A training model that can cover the implementation procedure for "power users" needs more attention and requires further research and investigation.

Open source ERP systems are becoming popular these days, especially for SMEs which have limited budgets to spend on expensive proprietary systems. There is a lack of research in the area of training for open source ERP systems. None of the above training models used any open source ERP systems and most of them are following the materials and methods supported by property ERP providers through their academic alliance programs (e.g. SAP Academic Alliance $\left.{ }^{\circledR}\right)$

In the industry and to conduct training, there are two important groups, particularly end users and power users. Companies may prefer to have the training to be conducted for power users also regarded as key users in the organisation who have a good understanding of the whole business process in departments and an overall understanding of the functionality of the ERP system that has been implemented. The mechanism is to focus on the key user to transfer the knowledge and then the key user will conduct the internal training for the end users. This important fact which is a common practice in small and many mid-sized companies has not been investigated by researchers yet, and there is no model to address training methods to plan for such group.

There is only one research stating that there is a possibility to conduct an ERP training to the end users so that they can implement the system without consulting. They validated the statement. However, they did not discuss the elements of the model. It is recommended that researchers investigate this area further for future outlook.

ERP training is not only an important area of research in the ERP systems for academicians, but it also plays an important role in the ERP implementation and is a critical success factor of million-dollar investments in the ERP system. Likewise its result has great potential to be applied in industry. Therefore, the present paper provides an initial literature review of ERP training to shed the lights on the past and present. It is suggested for researchers to investigate this topic further to address the identified research gaps and to contribute to the future direction of ERP training. 


\section{References}

Albadri, F. A., \& Abdallah, S. (2009). ERP Training and Evaluation: ERP Life-Cycle Approach to End-Users' Characterization and Competency Building in the Context of an Oil $\mathcal{E}$ Gas Company. Norristown: Int Business Information Management Assoc-Ibima.

Aldrich, C. (2000). Customer-focused e-learning: The drivers. Training \& Development, 54(8), 34-34.

Ali, A. H. M. (2014). ICT Facts and Figures. Retrieved from www.mis.iran.ir

Arasanmi, Chris N.; Wang, William Y.C.; Singh, Harminder; and Ekundayo, Samuel, "What Motivate End-Users To Transfer Gained Knowledge From Enterprise Systems Training?" (2011). PACIS 2011 Proceedings. 17. https://aisel.aisnet.org/pacis2011/17

Arasanmi, C. N., Wang, W. Y. C., \& Singh, H. (2013). The Influence of System Interface, Training Content and It Trust on ERP Learning Utilization: A Research Proposal. In L. Uden, F. Herrera, J. B. Perez, \& J. M. C. Rodriguea (Eds.), 7th International Conference on Knowledge Management in Organizations: Service and Cloud Computing (Vol. 172, pp. 153161). Berlin: Springer-Verlag Berlin.

Bradford, M., Vijayaraman, B., \& Chandra, A. (2003). The status of ERP integration in business school curricula: results of a survey of business schools. Communications of the Association for Information Systems, 12(1), 26.

Bryman, A. (2012). Social research methods: Oxford University Press.

Dalveren, Y. (2014). Using E-Learning in Enterprise Resource Planning (ERP) Training: A Case Study to Assist Curriculum Designers in Turkey. 5th World Conference on Educational Sciences, 116, 1353-1357. doi:10.1016/j.sbspro.2014.01.396

Esteves, J. M. (2014). An empirical identification and categorisation of training best practices for ERP implementation projects. Enterprise Information Systems, 8(6), 665-683. doi:10.1080/17517575.2013.771411

Esteves, J. M., Carvalho, J., \& Santos, A. A. (2002). Towards an ERP Life-Cycle Costs Model. In N. Fiona Fui-Hoon (Ed.), Enterprise Resource Planning: Solutions and Management (pp. 5162). Hershey, PA, USA: IGI Global.

Fan, J. C. J., Guh, W. Y., Chou, C. H., Ku, W. L., \& Sher, P. J. (2004). The effect of computer selfefficacy and training on intention to use ERP. Hangzhou: Zhejiang Univ Press.

Forrester, J. W. (1995). The beginning of system dynamics. McKinsey Quarterly, 4-17.

Hitchcock, L. (2005). Industry certification: value, validity, and a place for SoDIS®. ACM SIGCSE Bulletin, 37(4), 59-63.

Huang, W. F., Yu, Z. H., \& Liu, Y. C. (2013). Analysis on the Integrated Teaching Mode of ERP Course Based on CDIO. Newark: Information Engineering Research Inst, USA.

Ip, W. H., Lai, C. L., \& Lau, C. W. (2004). A web-based training model of enterprise resources planning for the manufacturing industry. International Journal of Engineering Education, 20(5), 733-741.

Jing, Y., Hua, J., \& Ieee. (2008). Research on Model of Teaching about ERP Platform Simulation in MIS Education. New York: IEEE. 
Kale, V., \& Kale, V. (2000). Implementing SAP R/3: The guide for business and technology managers: Sams.

Koh, S., Gunasekaran, A., \& Cooper, J. (2009). The demand for training and consultancy investment in SME-specific ERP systems implementation and operation. International Journal of Production Economics, 122(1), 241-254.

Koh, S. C. L., Gunasekaran, A., \& Cooper, J. R. (2009). The demand for training and consultancy investment in SME-specific ERP systems implementation and operation. International Journal of Production Economics, 122(1), 241-254. doi:10.1016/j.ijpe.2009.05.017

Lee, C. C., \& Bradley, J. (2004). ERP systems training at a university: A case study. Hershey: Idea Group Publishing.

Lin, S. H., Lin, H. Y., \& Kao, P. L. (2013). Study on Effects of Innovation and Vocational Training on Operation Performance by Implementation of ERP. In J. Zhang, Z. J. Wang, S. R. Zhu, \& X. M. Meng (Eds.), Information Technology Applications in Industry, Pts 1-4 (Vol. 263-266, pp. 3260-3264). Stafa-Zurich: Trans Tech Publications Ltd.

LinkedIn. (2015). Mustafa Rangwala । LinkedIn. Retrieved from https://in.linkedin.com/in/mustufa-rangwala-0a46777

Macris, A. M. (2009). Enterprise Resource Planning: An Applications' Training Aid Based on Semantic Web Principles. In M. D. Lytras, J. M. Carroll, D. Avison, A. Dale, J. Sipior, E. Damiani, R. D. Tennyson, A. Naeve, P. Lefrere, F. Tan, \& G. Vossen (Eds.), Visioning and Engineering the Knowledge Society: A Web Science Perspective, Proceedings (Vol. 5736, pp. 366-375). Berlin: Springer-Verlag Berlin.

Mahadevan, V., Agbinya, J., Braun, R., \& Ieee. (2006). Analyzing usability alternatives in multicriteria decision making during ERP training. New York: IEEE.

Mahapatra, R. K., \& Lai, V. S. (1998). Intranet-based training facilitates ERP system implementation: A case study. Atlanta: Association Information Systems.

Montandon, C., \& Zentriegen, M. (2003). Applications of customer focused e-learning. Informing Science, 1227-1237.

Motahar, S. M., Safie, N., Mukhtar, M., Aljunid, S., \& Mostafavi, S. (2013). An Applied Approach to Teach Hospital Information Systems Development Using an Open Source ERP Framework. Procedia Technology, 11, 1259-1265.

Mozaffar, H., \& Mozaffar, F. (2009). Process-Oriented User Training for Enterprise Resource Planning Systems. Los Alamitos: Ieee Computer Soc.

Nelson, K., \& Somers, T. (2001). Exploring ERP success from an end-user perspective. AMCIS 2001 Proceedings, 206.

Noudoostbeni, A., Ismail, N. A., Jenatabadi, H. S., \& Yasin, N. M. (2010). An Effective EndUser Knowledge Concern Training Method in Enterprise Resource Planning (ERP) Based on Critical Factors (CFs) in Malaysian SMEs. International Journal of Business $\mathcal{E}$ Management, 5(7).

Noudoostbeni, A., Yasin, N. M., \& Jenatabadi, H. S. (2009a). A mixed method for training ERP systems based on knowledge sharing in Malaysian Small and Medium Enterprise 
(SMEs). Paper presented at the International Conference on Information Management and Engineering, 2009. ICIME'09.

Noudoostbeni, A., Yasin, N. M., \& Jenatabadi, H. S. (2009b). To investigate the success and failure factors of ERP implementation within Malaysian small and medium enterprises. Paper presented at the International Conference on Information Management and Engineering, 2009. ICIME'09.

Pantelic, O., Pajic, A., \& Vujaklija, D. B. (2012). PERFORMANCE EVALUATION OF ERP SYSTEMS TRAINING PROGRAM. Inted2012: International Technology, Education and Development Conference, 6068-6074.

Scott, J. E., \& Walczak, S. (2009). Cognitive engagement with a multimedia ERP training tool: Assessing computer self-efficacy and technology acceptance. Information \& Management, 46(4), 221-232.

Shea, T., \& Khalil, O. (2004). ERP training effectiveness: A field experience from a higher education institution. Hershey: Idea Group Publishing.

Shtub, A. (2001). A framework for teaching and training in the Enterprise Resource Planning (ERP) era. International Journal of Production Research, 39(3), 567-576.

Sumner, M. (1999). Critical success factors in enterprise wide information management systems projects. Paper presented at the Proceedings of the 1999 ACM SIGCPR conference on Computer personnel research.

Wang, Y., Li, M., \& Yang, X. J. (2012). The design and realization of ERP system for Staff Training. In W. Z. Chen, X. P. Xu, P. Q. Dai, \& Y. L. Chen (Eds.), Advanced Manufacturing Technology, Pts 1-4 (Vol. 472-475, pp. 3425-3429). Stafa-Zurich: Trans Tech Publications Ltd.

Zhang, C. S., Li, Z. X., \& Chen, H. Y. (2011). Teaching Reform of ERP Sand Table for Enhancing the Entrepreneurial Ability of College Students. Hong Kong: Etp-Engineering Technology Press.

Copyright: (C 2018 Motahar, Mukhtar, Safie, Ma'arif \& Mostafavi. This is an open-access article distributed under the terms of the Creative Commons Attribution-NonCommercial 3.0 Australia License, which permits non-commercial use, distribution, and reproduction in any medium, provided the original author and AJIS are credited. 
Australasian Journal of Information Systems

2018, Vol 22, Research on Educational Technologies
Motahar, Mukhtar \& Safie

Towards a product independent ERP training model

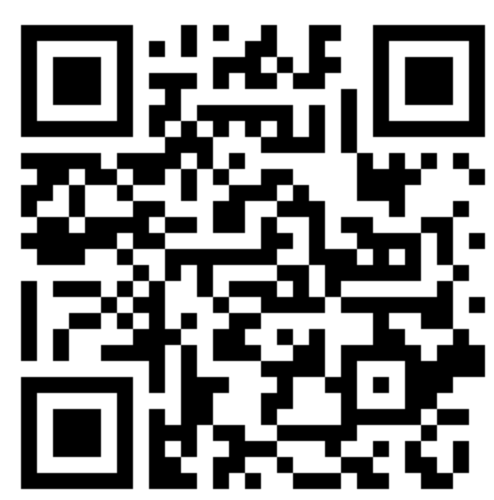

